International Journal of Current Research in
Biosciences and Plant Biology
Volume 5 • Number 1 (January-2018) ・ ISSN: 2349-8080 (Online)
PUBLISHERT

Original Research Article

doi: https://doi.org/10.20546/ijcrbp.2018.501.001

\title{
The Prevalence Study of Viral Hepatitis in AL-Najaf AL-Ashraf Province
}

\section{Ruaa Sheltagh Nile*, Doaa Amer Kadhim and Mohammed Abduaali Mohsin}

\author{
Laboratory Investigation Department, Faculty of Sciences, University of Kufa, Iraq
}

*Corresponding author.

\begin{tabular}{ll}
\hline A rticle Info & A B S TRA C T \\
\hline Date of Acceptance: & $\begin{array}{l}\text { This study was conducted to detect the prevalence of Hepatitis C virus and Hepatitis B } \\
\text { virus of infected Patients. The study was carried out in the period from January (2016) } \\
\text { 25 December 2017 }\end{array}$ \\
$\begin{array}{l}\text { to December (2016). The study included } 420 \text { hepatitis C and B virus suspected patients } \\
\text { from Al-Hakeem Hospital, AL-Sader Hospital and Middle Euphrates Hospital in Al- } \\
\text { 06 January 2018 }\end{array}$ & $\begin{array}{l}\text { Najaf Province with gender and age ranged from }(<10-70) \text { years old from both sexes. } \\
\text { Patients group was found to be } 120 \text { patients infected with Hepatitis represented47 }\end{array}$ \\
\hline Keyw ords & $\begin{array}{l}\text { Hepatitis C and 73 Hepatitis B the results of the study showed that the highest rate of } \\
\text { infection was in HBV. Our study found the male infected with hepatitis }(70.7 \%) \text { and } \\
\text { female infected with hepatitis }(29.2 \%) \text { so the male more infection for hepatitis then } \\
\text { female, also we found the patients children under }<10 \text { years less infected with hepatitis } \\
\text { and more age infected with hepatitis } 20-29 \text { and followed by age30-39 and } 40-49 .\end{array}$ \\
\hline
\end{tabular}

\section{Introduction}

\section{Viral hepatitis}

Viral hepatitis is liver irritation because of a viral contamination. It might show in intense or incessant structures (Vandelli, et al., 2004). The most widely recognized reasons for viral hepatitis are the five random hepatotropic infections Hepatitis A, Hepatitis B, Hepatitis C, Hepatitis D, and Hepatitis $\mathrm{E}$ that contaminate the liver. Notwithstanding the ostensible hepatitis infections, different infections that can likewise cause liver irritation incorporate Cytomegalovirus, Epstein- Barr infection, and Yellow fever. Most passings are because of hepatitis B and hepatitis C. (El-Serag and Rudolph
2007) Persistent contamination with HBV speaks to a noteworthy medical issue around the world, with more than 350 million incessantly tainted patients in danger of creating liver sickness (Stauber, 2000).

Hepatitis B infection (HBV) disease is critical medical issue, as it can prompt endless hepatitis, liver cirrhosis, and hepatic carcinoma normal and is a rising worry in the clinical administration of patients due to expanded mortality, (Bhatti, et al., 2007). While Hepatitis $C$ is the most widely recognized blood-borne infection. More than 4 million people groups have been contaminated with the hepatitis $\mathrm{C}$ infection (HCV) eventually before, and around 2.7 to 3.9 million have not recuperated and have ceaseless disease (Bhatti et al., 2007). 


\section{Transmission of HBV}

The transmission of HBV by blood contaminated and blood products, needle sharing, reuse of contaminated razors by barbers, tattooing devices, haemo-dialysis, acupuncture needles and contaminated medical devices, during sexual intercourse and perinatally from mother to the newborn during birth or breast feeding. (Alain et al., 2002)

Almost all adults newly infected with HBV develop acute hepatitis with jaundice as a predominant feature results the broad spectrum of liver disease, ranging from subclinical infection to acute, selflimited hepatitis and fatal, fulminate hepatitis. Exposure to $\mathrm{HBV}$, may also result in an asymptomatic carrier state that can progress to chronic active hepatitis, cirrhosis of the liver, and eventually hepatocellular carcinoma (Ranger et al., 2002). Hepatitis Bis not spread by contaminated food or water, and cannot be spread through casual or social contact such as kissing, sneezing or coughing, hugging, or eating food prepared by a person with hepatitis B. (Alain et al., 2002)

\section{Transmission of $\mathrm{HCV}$}

It is believed that HCV can be transmitted sexually, but that such transmission is inefficient.

Tattooing, as well as many body piercing practices, such as acupuncture and ear-piercing, have contributed significantly to the spread of $\mathrm{HCV}$, even in industrial nations. Needle-stick injuries, contaminated medical equipment, and blood spills in health care settings are also responsible for many cases of HCV. (Vandelli, et al., 2004)

The most significant risk behavior for $\mathrm{HCV}$ infection is drug use, particularly I.V. and is responsible for about $30-40 \%$ of all identified cases of hepatitis C. the sharing of contaminated needles and other drug paraphernalia increases the chance of infection dramatically Cocaine users have also been shown to transmit the virus by sharing snorting straws(Henderson, 2003).

\section{Pathogenesis of HBV}

Hepatitis B virus is dangerous because it attacks the liver, thus inhibiting the functions of this vital organ. The virus causes persistent infection, chronic hepatitis, liver cirrhosis, hepatocellular carcinoma, and immune complex disease. (Levine et al., 1994)

HBV infection in itself does not lead to the death of infected hepatocytes. HBV is a non-cytolytic infection. Liver damage however, arises from cytolytic effects of the immune system's cytotoxic $\mathrm{T}$ lymphocytes (CTL) which attempt to clear infection by killing infected cells. The strength of the CTL response has been noted to determine the course of the infection. For example, a vigorous CTL response results in clearance and recovery, although often with an episode of jaundice. A weak response results in few symptoms and chronic infection (and hence higher susceptibility for hepatocellular carcinoma) (Alain et al., 2002)

The younger a person when become infected with $\mathrm{HBV}$, the more likely asymptomatic and become a chronic carrier of the disease. Babies born to infected mothers are at very high risk of to becoming carriers and developing liver pathology. (Henderson, 2003)

\section{Pathogenesis of $\mathrm{HCV}$}

The chronic hepatitis $\mathrm{C}$ virus (HCV) infects approximately 130 million people worldwide It is estimated that approximately $15 \%$ of $\mathrm{HCV}$-infected individuals eliminate the virus spontaneously, that $25 \%$ develop a mild form of the disease, and that $60 \%$ develop the chronic progressive form (Alter.,2007)The elimination or persistence of HCV infection depends on the balance between the effectiveness, specificity and rapidity of the innate and adaptive immune responses, as well as on the $\mathrm{HCV}$ replication rate. Persistence of $\mathrm{HCV}$ can also be caused by infection at extra hepatic sites, (Shastry, et al., 2011)

Fibrosis is the principal complication of chronic hepatitis C, and it is estimated that $20 \%$ of patients 
develop cirrhosis over a period of 10,20 or 30 years The progression of fibrosis increases morbidity and mortality in chronic hepatitis $\mathrm{C}$ since it can lead to death due to complications caused by cirrhosis or hepatocarcinoma (Pawlotsky, 2007)

\section{Structure of Hepatitis B}

Hepatitis B virus is a member of the Hepadnavirus family. The virus particle, called Dane particle (virion), consists of an outer lipid envelope and an icosahedral nucleocapsid core composed of protein. The nucleocapsid encloses the viral DNA and a DNA polymerase that has reverse transcriptase activity similar to retroviruses. (Chang, 2011) The outer envelope contains embedded proteins which are involved in viral binding of, and entry into, susceptible cells. The virus is one of the smallest enveloped animal viruses with a virion diameter of $42 \mathrm{~nm}$, but pleomorphic forms exist, including filamentous and spherical bodies lacking a core. These particles are not infectious and are composed of the lipid and protein that forms part of the surface of the virion, which is called the surface antigen ( $\mathrm{HBsAg}$ ), and is produced in excess during the life cycle of the virus (Chang, 2011)

\section{Structure of Hepatitis C}

The hepatitis $\mathrm{C}$ virus particle consists of a core of genetic material (RNA), surrounded by an icosahedral protective shell of protein, and further encased in a lipid (fatty) envelope of cellular origin. Two viral envelope glycoproteins E1 and E2, are embedded in the lipid envelope (Silva and Fonseka, 2002)

\section{Replication Cycle of HBV}

HBV (Hepatitis-B Virus) belongs to a family of closely related DNA viruses called the Hepadnaviruses. The HBV nucleocapsid a relatively small and duplex circular DNA, viral polymerase and core protein. The life cycle of HBV is believed to begin when the virus attaches to the host cell membrane via its envelope proteins. It has been suggested that HBV binds to a receptor on the plasma membrane that is predominantly expressed on human hepatocytes via the pre-S1 domain of the large envelope protein as an initial step in HBV infection. (Chalana et al., 2013)

The replication of $\mathrm{HBV}$ can be regulated by a variety of factors, including hormones, growth factors, and cytokines. After the viral genome reaches the nucleus, the viral polymerase converts the partial dsDNA (double stranded DNA) genome into cccDNA (covalently closed circular DNA). This DNA is transcribed by host RNA Pol-II, and the resulting DNA is the template for RNA (Zidan, et al., 2012). The synthesis of the two viral DNA strands is sequential. The first DNA strand is made from the RNA template; during or after the synthesis of this strand, the RNA template is degraded and the synthesis of the second DNA strand proceeds, with the use of the newly made first DNA strand as a template, where their newly minted DNA genomes can be converted to cccDNA to maintain a stable intranuclear pool of transcriptional templates $\mathrm{HBV}$ surface (HBsAg) proteins are initially synthesized and polymerized in the rough endoplasmic reticulum. (Chalana et al., 2013)

These proteins are transported to the post ER and pre-Golgi compartments where budding of the nucleocapsid follows. The assembled HBV virion and sub-viral particles are transported to the Golgi for further modification of its glycans in the surface proteins, and then are secreted out of the host cell to finish the life cycle. (Zidan, et al., 2012)

\section{Replication Cycle of $\mathrm{HCV}$}

HCV belong to the flavivirus family. Replication of $\mathrm{HCV}$ involves several steps. The virus replicates mainly in the hepatocytes of the liver, where it is estimated that daily each infected cell produces approximately fifty virions (virus particles) with a calculated total of one trillion virions generated. The virus may also replicate in peripheral blood mononuclear cells, potentially accounting for the high levels of immunological disorders found in 
chronically infected HCV patients (Schrier, 2010). Entry into host cells occur through complex interactions between virions and cell-surface molecules CD81, LDL receptor, SR-BI, DCSIGN, Claudin-, and Occludin (Sebasteao and Raymundo 2006). RNA replication takes places via the viral RNA-dependent RNA polymerase which produces a strand RNA intermediate. The strand RNA then serves as a template for the production of new strand viral genomes. Nascent genomes can then be translated, further replicated or packaged within new virus particles. New virus particles are thought to bud into the secretary pathway and are released at the cell surface (Cotran, et al., 2005)

\section{Treatment of HVB}

\section{HBV can be treatment by many drugs include}

Interferon alfa-2b (Intron A). This synthetic version of a substance produced by the body to fight infection is used mainly for young people with hepatitis B who don't want to undergo long-term treatment or who might want to get pregnant within a few years. It's given by injection. Side effects may include depression, difficulty breathing and chest tightness (Garcia, et al., 2005).Liver transplant. If liver has been severely damaged, a liver transplant may be an option. During a liver transplant, the surgeon removes your damaged liver and replaces it with a healthy liver. Most transplanted livers come from deceased donors, though a small number come from living donors who donate a portion of their livers. Most people who have acute hepatitis C don't get treated, because they don't know that they have the virus. (Valsamakis, et al., 2007)

The vaccine is highly effective in preventing HBV It is estimated that $>90 \%$ of countries routinely vaccinate newborns against HBV, and approximately $70 \%$ are now delivering 3 immunization doses.

Since then, the number of HBV carriers in the juvenile population has been greatly reduced, and incidence of among children 6-14 years was reduced by $65 \%-75 \%$ (Murray et al., 2007)

\section{Treatment of hepatitis $\mathrm{C}$}

Treatment acute hepatitis $\mathrm{C}$ infection with alpha interferon decrease the number of patients that become chronic carriers get treated with medicine. (Ishida, et al., 2002) In these cases, treatment may help prevent long-term (chronic) infection, although there is still some debate over when to begin treatment and how long to treat acute hepatitis C. there is no vaccine for HCV (Murray et al., 2007)

\section{Materials and Methods}

\section{Patients}

All blood samples were collected from AL-Hakeem Hospital AL-Sadar Hospital and middle Euphrats Hospital in AL-Najaf City, during the period from January (2015) to December (2015). Total of 420 patients were suspected with hepatitis $C$ and $B$ virus from different cases.120 infected patients represented 47 cases of hepatitis $C$ virus and 73 cases from hepatitis B and 300 non infected with Hepatitis

\section{Blood samples collection}

$3 \mathrm{ml}$ of blood venous were withdrawn from $\mathrm{HCV}$ and HBV suspected individuals were collected in two EDTA tubes

\section{Detection of hepatitis $C$ and $B$ virus}

The detection of IgG specific for $\mathrm{HCV}$ and $\mathrm{HBV}$ were done by the use of third generation of ELISA technique. Anti-HCV IgG and Anti-HBV IgG ELISA from DALAB and the assay was preformed according to manufacturer's instructions.

\section{Results and Discussion}

\section{Clinical sample distribution}

Our study include collected of $420(100 \%)$ patients from AL-Sader hospital, Middle Euphrates Hospital and AL-Hakeem Hospital in AL-Najaf AL-Ashraf from January 2014 to December 2014 year the 
study found $120(28.5 \%)$ patient give positive result because they infected with hepatitis virus and300(71.5\%) give negative result (Table 1 and Fig. 1), while the result of other study of Rasha and basima, 2014 they found the prevalence of hepatitis $32 \%$ Viral hepatitis has emerged as a major public health problem throughout the world affecting several hundreds of millions of people. Viral hepatitis is a cause of considerable morbidity and mortality in the human population, both from acute infection and chronic sequelae which include, in the case of hepatitis $\mathrm{B}$ and $\mathrm{C}$ chronic active hepatitis and cirrhosis (Abdul Hussein and AL-Janabi, 2011). Hepatocellular carcinoma which is one of the ten most common cancers worldwide, is closely associated with hepatitis $\mathrm{B}$, and at least in some regions of the world with hepatitis $\mathrm{C}$ virus. Hepatitis B virus is among the common viral infectious agents of public health importance globally (Abdul Hussein and AL-Janabi, 2011). Two billion people are infected worldwide with approximately 350 million others suffering the chronic form of the hepatitis (Motta et al., 2012)
In this study the hepatitis represented 47(39.2\%) with HCV and 73 (60.8\%)for HBV (Table 1 and Fig. 2), so the study of Williams et al., 2014 found the HVB 11.0\% and Rasha and basima,2014 found the prevalence rates of $\mathrm{HBV}$ infection is $32.7 \%$ and study conducted in Basrah, Iraq by Jasim., et al., 2016 who showed that $44.52 \%$ of patents had HBV and found the prevalence of HCV $6 \%$ and Weber et al., 2001. Found the Prevalence of HCV 2\% studied. The global prevalence of $\mathrm{HCV}$ is estimated to be $2 \%$ (approximately 180 million people worldwide) and varies considerably among different regions Phylogenetic studies of $\mathrm{HCV}$ diversity described the chronology of the spread of $\mathrm{HCV}$ epidemics in many region in world (Weber et al., 2001).

Hepatitis B virus (HBS) is one of the most human pathogens in which more than 350 million people worldwide are persistently infected with HBV and are at risk of developing chronic liver diseases, cirrhosis and hepatocellular carcinoma (Harris, 2002)

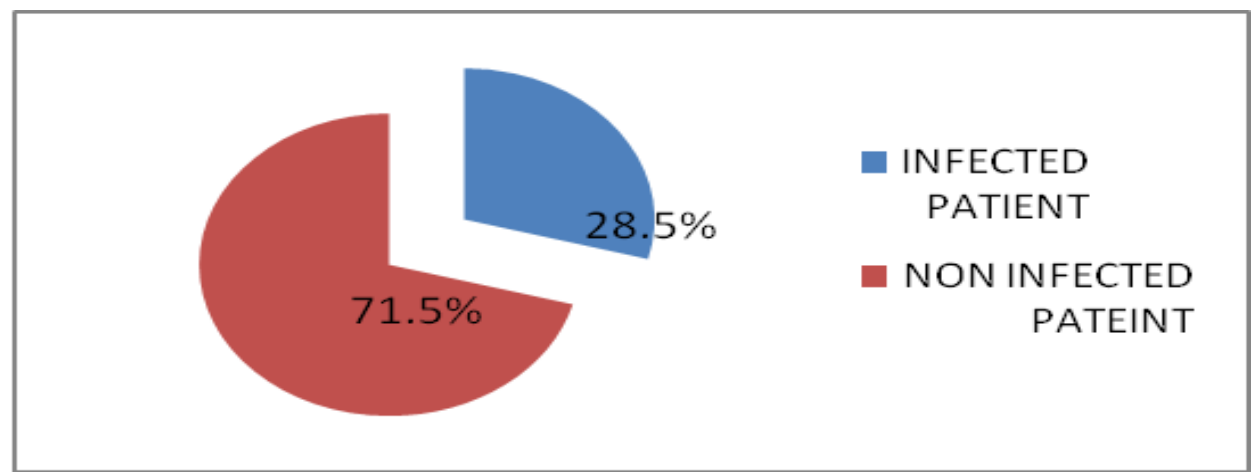

Fig. 1: Percentage of prevalence of hepatitis.

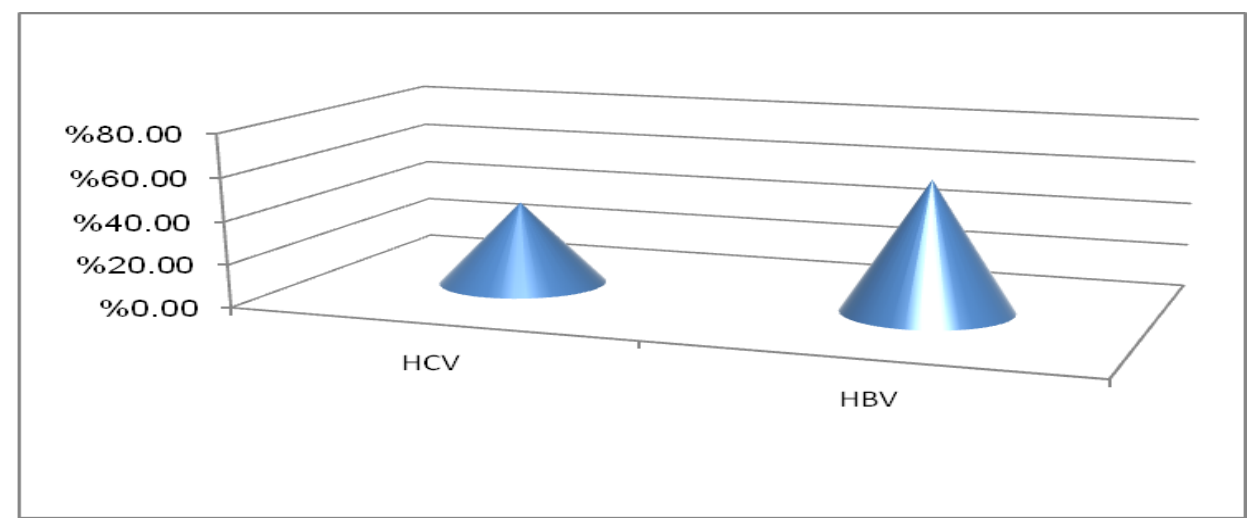

Fig. 2: Prevalence of hepatitis B and C. 


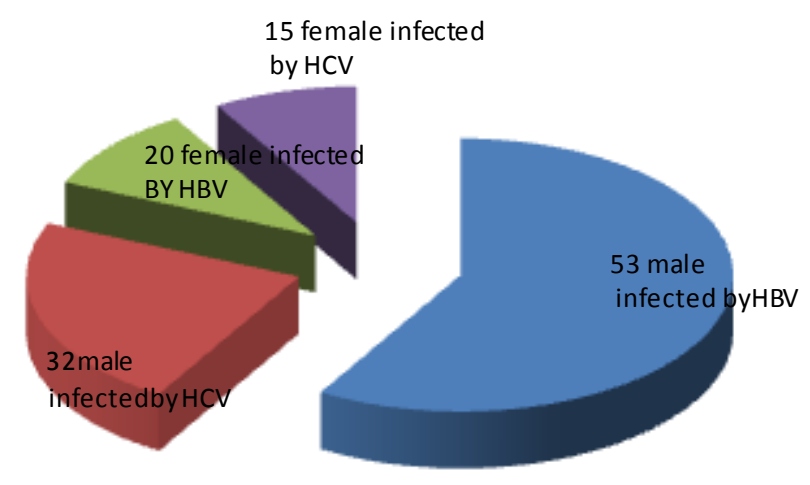

Fig. 3: Distribution of hepatitis according to gender.

Table 1. Prevalence of hepatitis virus.

\begin{tabular}{|c|c|c|c|}
\hline Hepatitis HCV & Hepatitis HBV & Hepatitis HCV & Hepatitis HBV \\
\hline \multicolumn{3}{|c|}{ Negative } & \multicolumn{3}{|c|}{ positive } \\
\hline 115 & 185 & 47 & 120 \\
\hline 300 & $420(100 \%)$ \\
\hline
\end{tabular}

Table 2. Distribution of hepatitis in gender.

\begin{tabular}{|c|c|c|c|}
\hline \multicolumn{2}{|c|}{ H CV } & \multicolumn{2}{c|}{ HBV } \\
\hline \multicolumn{2}{|c|}{ Positive } & Fositive \\
\hline Female & Male & 20 & Male \\
\hline 15 & 32 & \multicolumn{2}{c|}{73} \\
\hline
\end{tabular}

Table 3. Distribution of patients according to age.

\begin{tabular}{|c|c|c|c|c|c|}
\hline \multirow{2}{*}{ AGE(years) } & \multicolumn{2}{|c|}{ HBV } & \multicolumn{2}{c|}{ HCV } & \multirow{2}{*}{ Total } \\
\cline { 2 - 5 } & Female & Male & Female & Male & \\
\hline$<10$ & $1(0.8 \%)$ & $2(1.6 \%)$ & 0 & $2(1.6 \%)$ & 5 \\
\hline $10-19$ & $2(1.6 \%)$ & $6(4.8 \%)$ & $3(2.5 \%)$ & $4(3.3 \%)$ & 15 \\
\hline $20-29$ & $7(5.8 \%)$ & 13 & $5(4 \%)$ & $7(5.8 \%)$ & 32 \\
\hline $30-39$ & $4(3.3 \%)$ & $9(8.1 \%)$ & $1(0.8 \%)$ & $10(8.3 \%)$ & 24 \\
\hline $40-49$ & $3(2.5 \%)$ & $12(10 \%)$ & $3(2.5 \%)$ & $4(3.3 \%)$ & 22 \\
\hline $50-59$ & $2(1.6 \%)$ & $8(6.4 \%)$ & $2(1.6 \%)$ & $3(2.5 \%)$ & 15 \\
\hline $60-70$ & $1(0.8 \%)$ & $3(2.5 \%)$ & $1(0.8 \%)$ & $2(1.6 \%)$ & 7 \\
\hline \multirow{2}{*}{ Total } & 20 & 53 & 15 & 32 & \multirow{2}{*}{120} \\
\cline { 2 - 5 } & 73 & & \\
\cline { 2 - 4 }
\end{tabular}




\section{Clinical Sample Distribution According to Gender}

Our study found the male and female infected with hepatitis(70.7\%) and (29.3\%) respectively represented by (44.2\%) of male and $(16.6 \%)$ of female infected by HBV and(26.6\%) of male and (12.6\%) of female infected by HCV respectively (Table 2 and Fig. 3). This study agree with study of Williams et al., 2014 found (95.2\%) of males and $(4.8 \%)$ of females were infected respectively, Imad, 2013 found $(40.0 \%)$ of men infected with hepatitis and female $(25 \%)$ infected with hepatitis. Our study found the male infected with hepatitis by percent (27\%) more than the female, males donate blood more often than females. In most human populations there is a higher prevalence of chronic carriers of hepatitis virus among males than females. Females are more likely than males to produce anti-hepatitis in response to infection. Diseases associated with increased frequencies of carriers are more prevalent among males. (Chakravarti et al., 2005 and Tanaka et al., 2006).

\section{Clinical Sample Distribution According to Age}

According to our study found the hepatitis more distributed in age 20-29 and followed by age 30-39 and 40-49 and less in age < 10. The other study found The female give $9.6 \%$ in age group $<20$ years and male $16.4 \%$ (Lok, 2002), while donors in age group (40 -49) had the least prevalence of 5.9\% female donors and was $8.5 \%$ among male donors by Williams., et al., 2014, while Kumar., et al., 2010 found the male give (49\%) and female (51\%) in age (20-29) years and found the infected with hepatitis in age $\leq 50$ years include male $(32.7 \%)$ and female $(13.0 \%)$

There was a larger proportion of carriers among the offspring when mothers rather than fathers were carriers this suggested that transmission from the mother to the offspring was a more likely event than transmission from the father to the offspring. That mothers but not fathers often transmitted hepatitis virus to their offspring. The infection from the parents (primarily mothers) could occur when the children were quite young and that the children would remain carriers for a long time. (Lok, 2002) women who were asymptomatic carriers during pregnancy were very likely to infect their infants, and such babies had a high risk of becoming carriers The time at which mother-to-child infection takes place could occur in uterus, during birth, or in the early postnatal period (Salaudeen et al., 2011).the study revealed an age effect on the prevalence of hepatitis among the studied population. The highest prevalence was seen among donors in age group $<30$ years. Less frequently infected with hepatitis had positive in patient less than 70 years (Reekie et al., 2014)

The prevalence of Hepatitis surface antigen is slightly higher in males than females In female group (Emad et al., 2012) Risk factor for HBV infection may vary considerably depending on epidemiological data, the geographic region and the social, cultural characteristics of different population (Fang et al., 2009) The risk factors were included i.e. gender and age in which it has been found that Hepatitis infection in men (51\%) is higher than that in women (48.9\%) within the age group of 20-60 years. who found that men had a higher rang of HBV infection, it is generally agreed that risk of chronic HBV infection is inversely related to age of onset of infection and that children become chronic most often and represent the most important reservoir of infection in the comminutes (Saberton et al., 2009). Males are more susceptible to chronic infection than are females; males and females may both become infected at about the same rate, depending on their exposure to infection but males are more likely to become chronically infected than females.

And people who are more chronically infected are more apt to go on to get chronic liver disease and primary cancer of the liver than people who are not chronically infected. But even among chronically infected people, males seem to be more prone to go on to pathology than females, females do get these diseases, and do get cancer of the liver, but the ratio is higher for males compared to females. (Smith et al., 2011) 


\section{References}

Abdul Hussein A, AL-Janabi S. 2009. Efficiency the Application of HBV Vaccination Program to Clinical Laboratory Workers against Hepatitis B Infection in Karbala-Iraq Asian J of Med. Sci. 1(2): 54-56,

Alain S, Loustaud-Ratti V, Dubois F, Bret MD, Rogez S, Vidal E, Denis F 2002. Seroreversion from hepatitis $\mathrm{C}$ after needle stick injury. Clin. Infect. Dis. 34:717-719.

Alter M.J. 2007 Epidemiology of hepatitis C virus infection. World J Gastroenterology; 13(17):2436-41.

Bhatti, F.A.; Ullah, Z.; Salamat, N.; Ayub, M. and Ghani, E. 2007 Anti-hepatits B core antigen testing, viral markers, and occult hepatitis B virus infection in Pakistani blood donors: implications for transfusion practice. J Med. Bio., 47(1):74-9.

Chakravarti A, Rawat D, Jain M. 2005. A study on the perinatal transmission of the hepatitis B virus. Indian J. Med. Micro. 23(2):128-30.

Chalana H, Singh H, Sachdeva JK, Sharma S. 2013. Seroprevalence of human immunodeficiency virus, hepatitis B surface antigen, and hepatitis $\mathrm{C}$ in substance dependents admitted in a tertiary hospital at Amritsar, India. Asian J Psychiatr; 6: 552-5

Chang MH 2011. Hepatitis B virus and cancer prevention. Recent Results Cancer Res.; 188:75-84

Cotran, RS S.; Kumar, Vinay; Fausto, Nelson; Robbins, Stanley L.; Abbas, Abul K., Robbins and Cotran, 2005. Pathologic basis of diseasell. St. Louis, MO: Elsevier Saunders. 189-320.

De Silva HJ, Fonseka MMD. 2002. Seroepidemiology of Hepatitis $C$ in SAARC countries. In: Sarin SK, Okuda K (Eds) Hepatitis B and C: from Carrier to Cancer. New Delhi: Harcourt (India) Elsevier Science,: 187200.

El-Serag HB and Rudolph KL 2007. Hepatocellular carcinoma: epidemiology and molecular carcinogenesis. Gastroenterology. 132(7):255776.

Emad-Aldin Ibrahim Osman, Nagwa Ahmed
Abdulrahman, Osman Abbass, 2015. Evaluation Study of Patients Infected with Chronic Hepatitis C in Iraq Laith H. Muhsun.

Fang Y., Shang QL., Liu JY., Li D., et al. 2009. Prevalence of occult hepatitis B virus infection among hepatopathy patients and healthy people in china. J. Infect. 58:383-8.

Garcia L. R. Kemp P., and Molineux I. J. 2005. Changes in bacteriophage $\mathrm{T} 7$ virion structure at the initiation of infection Virology, $J$. Gastroenterology 340, 307-317

Harris KR, Dighe AS. Laboratory testing for viral Hepatitis 2002. Am J Clin Pathol; 118:S18-S25.

Henderson DK 2003. Managing occupational risks for hepatitis $\mathrm{C}$ transmission in the health care setting. Clin. Microbiol. Rev. 16:546-568.

Imad s. Mahmoud 2013. Hepatitis B and C: from Carrier to Cancer. Tikrit Medical J; 19(2):280285

Ishida T, Takao S, Wannapa S, Tiwawech D. 2002. Prevalence of hepatitis B and C virus infection in rural ethnic populations of Northern Thailand. J Clin Virol; 24: 31-5.

Jasim N. Al-Asadi1, Nadia K. Abdul-Jalil 2016. seroprevalence of viral hepatitis $\mathrm{b}$ and $\mathrm{c}$ among pre-surgical patients in basrah, iraq. $\mathrm{j}$ med. of basrah university 5:89-99

Kumar, V; Das, S and Jameel, S. 2010.The biology and pathogenesis of hepatitis viruses. Current science. 98 (3): 312-325.

Levine OS, Vlahov D, Nelson KE 1994. Epidemiology of hepatitis B virus infections among injecting drug users: seroprevalence, risk factors and viral infections. Epidemiol. Rev. 16:418-436

Lok, A.S. 2002. Chronic Hepatitis B. J Med, 346, 1682-1683

Motta-Castro AR, Martins RM, Araujonm, Neilc, Fachioli GB. 2008. Molecular epidemiology and hepatitis B virus in an isolated AfroBrazilian community. Arch Virol 153:21972205.

Murray PR, Baron EJ, Jorgensen JH, Pfaller MA, Yolken RH, 2007. Manual of clinical microbiology. Washington DC: ASM Press; p. 1424-36.

Pawlotsky J.M. 2004. Pathophysiology of hepatitis 
$\mathrm{C}$ infection and related liver disease. Trends.j. Microl; 12(2):96-102

Ranger-Rogez S, Alain S, Denis F 2002. Hepatitis viruses: mother to child transmission Pathology. Biol. (Paris) 50:568-575.

Rasha. W. Salim Basima A. Abdullah 2014. The Prevalence of Hepatitis B Virus in High Risk Groups in Nineveh Governorate / Iraq.J. Baghdad Science Vol. 11(2)

Reekie JM, Levy MH, Richards AH et al., 2014. Trends in HIV, hepatitis B and hepatitis C prevalence among Australian prisoners - 2004, 2007, 2010. Med J Aust; 200: 277-80.

Saberton, P.J., Paez, A., Newbold, K.B. and Heddle, N.M. 2009. Geographical Variations in the Correlates of Blood Donor Turnout Rates: An Investigation of Canadian Metropolitan Areas.J. International of Health Geographics, 8, 56

Salaudeen, A.G., Musa, O.I., Awoyemi, A.O., Bolarinwa, A.O., Adegboye, A.O. and Samuel, S.O. 2011. Community Survey on Blood Donation Practices in a Northern State of Nigeria. J of Preventive Medicine and Hygiene, 52, 21-25.

Schrier R 2010. "Renal sodium excretion, edematous disorders, and diuretic use", Philadelphia, Lippincott Williams \& Wilkins,

Sebasteao V, Raymundo P, 2005. High prevalence of hepatitis $B$ virus and hepatitis $D$ virus in the Western Brazilian J. Amazon. Hyg. 73: 808-14.

Shastry, S. and Bhat, S.S. 2011. Prevention of posttransfusion hepatitis by screening of antibody to hepatitis B core antigen in healthy blood donors. Mediterr. J. Hematology. Infect. Dis.; 3(1): 2011062.
Smith, A., Matthews, R. and Fiddle, J. 2011. Blood Donation and Community: Exploring the Influence of Social Capital. J. International of Social Inquiry, 4, 45-63.

Stauber R 2000. Epidemiology and transmission of hepatitic C. Wien Med. Wochenschr, 150:460462

Tanaka Y, Kurbanov F, Mano S, et al., 2006. Molecular tracing of the global hepatitis $C$ virus epidemic predicts regional patterns of hepatocellular carcinoma mortality. Gastroenterology. Mar; 130(3):70314

Valsamakis A. 2007. Molecular testing in the diagnosis and 22. Management of chronic hepatitis B. Clin Microbiol Rev; 20 : 426-39.

Vandelli C, Renzo F, Romano L, Tisminetzky S, De Palma M, et al., 2004. Lack of evidence of sexual transmission of hepatitis $\mathrm{C}$ among monogamous couples: results of a 10-year prospective follow-up study. Am J Gastroenterol; 99:855-859.

Weber, B; Melchior, W; Gehrke, R; Doerr, HW; Berger, A and Rabenau, H. 2001. Hepatitis B virus marker in anti $\mathrm{HBc}$ only positive individuals. J. Med. Virol. 64: 309-312

Williams Walana1 Patrick Hokey2, Samuel Ahiaba 2014. Sero-Prevalence of Hepatitis B Virus Infection among Blood Donors: ARetrospective Study in the Kintampo Municipal Hospital, Ghana International License 7:56-89

Zidan A, Scheuerlein H, Schüle S, Settmacher U, Rauchfuss F. 2012. Epidemiological pattern of hepatitis B and hepatitis C as etiological agents for hepatocellular carcinoma in Iran and worldwide. Hepatitis Monthly; 12 -6894.

\section{How to cite this article:}

Nile, R. S., Kadhim, D. A., Mohsin, M. A., 2018. The prevalence study of viral hepatitis in AL-Najaf ALAshraf Province. Int. J. Curr. Res. Biosci. Plant Biol. 5(1), 1-9.

doi: https://doi.org/10.20546/ijcrbp.2018.501.001 